\title{
Monitoring of fish diseases in the Magadan region
}

\author{
E.A. Vitomskova* \\ Federal state budgetary scientific institution Magadan Research Institute of Agriculture Russian \\ Federation, Magadan, Russia
}

\begin{abstract}
In such a large region as the Far North-East of Russia, there is still no purposeful ichthyopathological study of fish diseases, which has epizootic and epidemiological significance. The material for the study was commercial fish caught in different seasons of 1995-2021. As a result of the research, individuals of natural populations and in aquaculture with clinical signs of infectious and parasitic diseases were found, and cultures of virulent strains of microorganisms were isolated. According to the results of the parasitological study, larvae of nematodes of the family Anisakidae and plerocercoids of cestodes Diphyllobothriidae, which have important epidemiological and epizootic significance, were registered. Based on long-term ichthyopathological studies, a retrospective review of own data was carried out. The analysis of infectious diseases of mature individuals of anadromous Pacific salmon of the genus Oncorhynchus, as well as long-term parasitological monitoring in a comparative aspect of the invasion of commercial fish by helminths dangerous to human and animal health, is presented.
\end{abstract}

\section{Introduction}

The fishing industry has played a central role in the region's economy at all times. Fishery pools abound in a variety of valuable fish species, such as chum salmon, coho salmon, sockeye salmon, pink salmon, halibut (Hippoglossus hippoglossus), halibut (Reinhardtius hippoglossoides), smelt, and greenling. Sea fish has always been considered as an item of healthy nutrition with easily digestible protein and microelements in it. It is difficult to overestimate the importance of fish and fish products in maintaining the food security of our country in general and the Magadan region in particular. Herring, halibut, cod, pollock, Pacific migratory salmon, flounder, and saffron cod have the largest share in the catch structure of fishing enterprises of the Magadan Region. Region. Fish processing factories fully provide not only the population of the region with various and high-quality food products, but also the regions of our country and abroad.

According to the state assignment, large fish-breeding enterprises of the region engaged in fish farming of Pacific anadromous salmon fish annually release juvenile fish of chum salmon, pink salmon, coho salmon, and sockeye salmon into natural water pools of the North Sea of Okhotsk basin. For example, in 2019, the plan of the release of juvenile

\footnotetext{
${ }^{*}$ Corresponding author: ekaterinaseymchan@mail.ru
} 
salmon was fulfilled by more than $100 \%$ : at the rate of the State Planning Commission 11.75 million juveniles, in fact, 12.58 million juveniles were released [2].

During the period of import substitution and the approved Doctrine of food security of our country, it is known that one of the main tasks of the fishery complex of the Russian Federation is to strengthen food security and provide the population with high-quality and affordable domestic (national) fish products.

This fully applies to the Magadan region, where it has become necessary to carry out ichthyopathological control of marine fish. Without a deep study of the problem in the field of fish diseases, it is impossible to prevent the occurrence of this or that disease or to fight it. Diseases of fish of various etiologies harm successful fish farming and, during outbreaks, reduce the effectiveness of indicators at aquaculture enterprises in the Magadan Region.

A certain species composition of marine fish is exposed to helminths, which determine the epidemiological significance. There are also parasites that are not dangerous for human health, but cause disgust when eating fish and fish products and spoil its commercial presentation. Anyway, the manifestation of fish diseases of any etiology impacts on the decline in economic indicators of activity in the fisheries industry. The foregoing determines the relevance and practical significance of research. In the structure of helminthic diseases of fish, pathogens of diphyllobothriasis and anisakidosis have largest share and they are widespread among commercial fish of the World Ocean in general and the northern Okhotsk Sea, in particular, and are of great epidemiological and epizootic significance [3, 4,5,6,7,8]. In artificial fish farming of salmon fish, there are problems connected with infectious and parasitic diseases, the causative agents of which affect both mature individuals from which the reproductive products are taken, and fertilized caviar and juveniles [9].

The aim of the work was to carry out ichthyopathological studies of marine commercial fish of natural populations and in aquaculture with the completion of monitoring.

\section{Materials and methods}

From 1995 to 2021, ichthyopathological studies and monitoring of fish diseases were carried out. The material for the study was 11 species of fish: chum salmon (Oncorhynchus keta), pink salmon (Oncorhynchus gorbuscha), coho salmon (Oncorhynchus kisutch), herring (Clupea harengus pallasi), smelt (Hypomesus olidus), smelt (Osmerus eperlanus dentex), halibut (Hippoglossus hippoglossus stenolepis), halibut (Reinhardtius hippoglossoides matsuurae), flounder (Acanthopsetta nadeshnyi) saffron cod (Eleginus gracilis), pollock (Theragra chalcogramma) of natural bodies of water in the Sea of Okhotsk and under aquaculture conditions.

Fish for research were caught in the Sea of Okhotsk and in rivers where reproductive products were selected from producers for fish farms (rivers Yama, Yana, Arman, Taui). Fertilized caviar and juveniles of anadromous Pacific salmon were collected from fish factoris. Ichthyopathological studies were carried out in accordance with generally accepted methods [1].

During the study of the parasite fauna, 7795 individuals of marine commercial fish were examined. For bacteriological tests, 2045 bacteriological inoculations were made, 1772 cultures of microorganisms were isolated and identified. Due to the fact that the location of the objects of selection of pathological material are at a remote distance from the microbiological laboratory, the primary bacteriological inoculations from fish, fertilized caviar, fish fry were performed on beef-extract broth and nutrient agar (meat infusion agar). A more detailed microbiological study was carried out under stationary conditions. Virulence of aeromonads was determined by using a DNA test [10]. Parasitological studies 
were carried out only under laboratory conditions, using methods of coloring parasites, determining their viability and processing data by the method of mathematical statistics.

\section{Results and discussion}

During the monitoring of marine fish diseases in natural bodies of water and in aquaculture conditions, pathogens of an infectious and parasitic nature were registered in different seasons of research. The research results are shown in table 1.

Table 1. Infection rate of marine fish with pathogens of infectious and parasitic diseases.

\begin{tabular}{|c|c|c|c|c|c|c|c|c|c|c|c|c|c|}
\hline \multirow[t]{2}{*}{ № } & \multirow[t]{2}{*}{$\begin{array}{c}\text { Disease } \\
\text { causative } \\
\text { agent }\end{array}$} & \multicolumn{2}{|c|}{$\begin{array}{c}\text { Chum salmon } \\
\text { (Oncorhynchus } \\
\text { keta) }\end{array}$} & \multicolumn{2}{|c|}{$\begin{array}{c}\text { Pink salmon } \\
\text { (Oncorhynchusgor } \\
\text { buscha) }\end{array}$} & \multicolumn{2}{|c|}{$\begin{array}{c}\text { Coho salmon } \\
\text { (Oncorhynchus } \\
\text { kisutch) }\end{array}$} & \multicolumn{2}{|c|}{$\begin{array}{c}\text { Herring } \\
\text { (Clupeaharengusp } \\
\text { allasi) } \\
\end{array}$} & \multicolumn{2}{|c|}{$\begin{array}{c}\text { Smelt } \\
\text { (Hypomesusoli } \\
\text { dus) } \\
\end{array}$} & \multicolumn{2}{|c|}{$\begin{array}{c}\text { Smelt } \\
\text { (Osmeruseperl } \\
\text { anusdentex) }\end{array}$} \\
\hline & & $\begin{array}{l}\text { Spe } \\
\text { cim } \\
\text { en } \\
\text { rese } \\
\text { arch } \\
\text { ed. }\end{array}$ & $\begin{array}{l}\text { EI, \%* } \\
\text { / II ** }\end{array}$ & $\begin{array}{l}\text { Speci } \\
\text { men } \\
\text { researc } \\
\text { hed. }\end{array}$ & $\begin{array}{l}\text { EI, \%/ } \\
\text { II }\end{array}$ & $\begin{array}{l}\text { Spe } \\
\text { cim } \\
\text { en } \\
\text { rese } \\
\text { arch } \\
\text { ed. }\end{array}$ & $\begin{array}{l}\text { EI,\%/ } \\
\text { II }\end{array}$ & $\begin{array}{l}\text { Speci } \\
\text { men } \\
\text { researc } \\
\text { hed. }\end{array}$ & $\begin{array}{l}\text { EI, \%* } \\
/ \text { II ** }\end{array}$ & $\begin{array}{l}\text { Spe } \\
\text { cim } \\
\text { en } \\
\text { rese } \\
\text { arch } \\
\text { ed. }\end{array}$ & $\begin{array}{l}\text { EI, \%/ } \\
\text { II }\end{array}$ & $\begin{array}{l}\text { Spe } \\
\text { cim } \\
\text { en } \\
\text { rese } \\
\text { arch } \\
\text { ed. }\end{array}$ & $\begin{array}{l}\text { EI,\% } \\
\text { / II }\end{array}$ \\
\hline 1 & $\begin{array}{l}\text { Aeromonash } \\
\text { ydrophila }\end{array}$ & 143 & 100,0 & 58 & 100,0 & 50 & 100,0 & & & & & & \\
\hline 2 & $\begin{array}{l}\text { Pseudomona } \\
\text { s capsulata }\end{array}$ & 98 & 100,0 & 35 & 100,0 & 25 & 100,0 & & & & & & \\
\hline 3 & $\begin{array}{l}\text { Phycomycet } \\
\text { es p. } \\
\text { Saprolegnia }\end{array}$ & 52 & 100,0 & 35 & 100,0 & 48 & 100,0 & & & & & & \\
\hline 4 & $\begin{array}{l}\text { Mixosomace } \\
\text { rebralis }\end{array}$ & 120 & 100,0 & & & & & & & & & & \\
\hline 5 & $\begin{array}{l}\text { Anisakis } \\
\text { simplex }\end{array}$ & 862 & $\frac{100,0}{11,5}$ & 1028 & $\frac{71,3}{4,7}$ & 320 & $\frac{98,9}{12,6}$ & 1745 & $\frac{91,2}{3,8}$ & 273 & $\frac{29,0}{1,9}$ & 288 & $\frac{36,9}{0,9}$ \\
\hline 6 & $\begin{array}{l}\text { Pseudoterra } \\
\text { novadecipie } \\
n s\end{array}$ & 862 & $\frac{71,8}{1,1}$ & 1028 & $\frac{12,4}{1,0}$ & 320 & $\frac{42,9}{3,6}$ & & & 273 & $\frac{71,0}{1,2}$ & 288 & $\frac{84,4}{1,4}$ \\
\hline 7 & $\begin{array}{l}\text { Diphylloboth } \\
\text { riumluxi }\end{array}$ & 35 & $\frac{2,8}{1,0}$ & 141 & $\frac{10,6}{1,0}$ & & & & & & & & \\
\hline 8 & $\begin{array}{l}\text { Diphylloboth } \\
\text { riumdendriti } \\
\text { cum }\end{array}$ & 25 & $\frac{20,0}{1,0}$ & 46 & $\frac{4,3}{1,0}$ & 320 & $\frac{1,7}{1,0}$ & & & & & & \\
\hline 9 & $\begin{array}{l}\text { Diphylloboth } \\
\text { riumsobolevi }\end{array}$ & & & & & & & & & 273 & $\frac{51,2}{4,9}$ & 288 & $\frac{61,8}{4,5}$ \\
\hline 10 & $\begin{array}{l}\text { Pyramicocep } \\
\text { halusphocar } \\
\text { um }\end{array}$ & & & & & & & & & & & & \\
\hline 11 & $\begin{array}{l}\text { Nybeliniasur } \\
\text { minicola }\end{array}$ & 130 & $\frac{20,7}{1.7}$ & 57 & $\frac{12,3}{1,1}$ & & & & & & & & \\
\hline 12 & $\begin{array}{l}\text { Corynosoma } \\
\text { strumosum }\end{array}$ & & & & & & & & & 273 & $\frac{91,5}{54,7}$ & 288 & $\frac{95,8}{49,0}$ \\
\hline
\end{tabular}

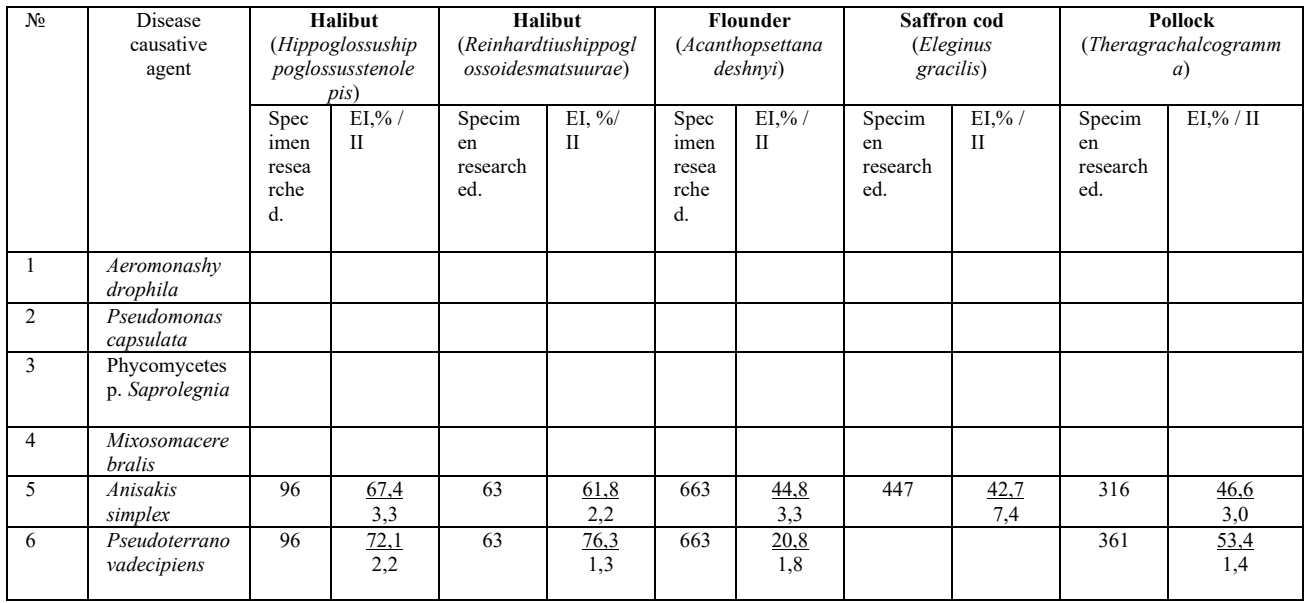




\begin{tabular}{|c|c|c|c|c|c|c|c|c|c|c|c|}
\hline 7 & $\begin{array}{l}\text { Diphyllobothri } \\
\text { umluxi }\end{array}$ & & & & & & & & & & \\
\hline 8 & $\begin{array}{l}\text { Diphyllobothri } \\
\text { umdendriticu } \\
m\end{array}$ & & & & & & & & & & \\
\hline 9 & $\begin{array}{l}\text { Diphyllobothri } \\
\text { umsobolevi }\end{array}$ & & & & & & & & & & \\
\hline 10 & $\begin{array}{l}\text { Pyramicoceph } \\
\text { alusphocarum }\end{array}$ & & & & & & & 483 & $\frac{55,2}{6,6}$ & 863 & $\frac{73,9}{7,7}$ \\
\hline 11 & $\begin{array}{l}\text { Nybeliniasurm } \\
\text { inicola }\end{array}$ & & & & & & & & & & \\
\hline 12 & $\begin{array}{l}\text { Corynosomast } \\
\text { rumosum }\end{array}$ & 96 & $\frac{98,9 * * *}{74,0}$ & 63 & $\frac{90,4^{* * *}}{79,5}$ & 663 & $\frac{56,2}{33,9}$ & 483 & $\frac{47,4}{44,7}$ & & \\
\hline
\end{tabular}

Notes:*EI (extent of infestation) - percentage of fish infestation;

**II (intensity of invasion) - number of larvae recorded in one infected fish

For the first time Aeromonas hydrophila in the conditions of the Magadan region was indicated in 1996 at the Arman salmon fish factory. As a result of the disease outbreak, about 100 thousand individuals of pink salmon juveniles died. The juveniles reacted weakly to irritation. At the post-mortem examination, the internal organs are hemorrhagically inflamed, and there is a large accumulation of ascitic fluid in the body cavity of the fish. The fish farming objects are provided with water from deep-water artesian wells. The lowtemperature regime of keeping juveniles affects their physiological status, slowing down their development. As a result of the bacteriological research, a pathogenic bacterium of the genus Aeromonas of the hydrophila species was isolated. In order to clarify the cause of the juvenile salmonids disease, epizootic and ichthyopathological studies of spawning rivers were carried out, where reproductive products are taken from the broodstock of anadromous salmon fish.

During the period of anadromous migration to spawning rivers, mature individuals of the Pacific anadromous salmon undergo significant physiological changes, which creates favorable conditions for the pathogenic microflora development and the occurrence of diseases. Pathogenic representatives of the genus Aeromonas of the species hydrophila, being the causative agents of aeromonosis and representatives of the aquatic habitat microflora all over the world, are often detected in salmon during the spawning period [11, 12].

Clinical examination revealed numerous erythema, necrosis of fins, abdominal distension and abscesses on the body surface, mainly below the midline of the body. Postmortem examination revealed an enlarged spleen, softening of the kidney, muscle hemorrhages, and abdominal ascites. Primary bacteriological inoculations were carried out at the place of the collection of reproductive products, following all possible aseptic rules.

Laboratory studies have isolated two species of bacteria Aeromonas hydrophila and Pseudomonas capsulata from different sets of mature chum salmon and pink salmon; and from the blood, internal organs and ascitic fluid of pink salmon, chum salmon and coho salmon - the monoculture Aeromonas hydrophila, which has a virulence. For all the years of aeromonosis diagnostics, the studied individuals of chum salmon (Oncorhynchusketa), pink salmon (Oncorhynchus gorbuscha) and coho salmon (Oncorhynchus kisutch) were $100.0 \%$ infected (Figure 1).

In order to find out the ways of transmission of infection to fish-breeding enterprises, the water which feeds fish-farming objects, fertilized eggs, larvae and juveniles were studied. Taking into account the fact that the fertilized eggs are routinely treated with special preparations before being placed in the incubation apparatus, we carried out its bacteriological examination. Bacteriological inoculation was carried out both from the surface of the eggs and from the contents. The study material of the larvae was the content of the yolk sac, and of the juveniles - the ascitic fluid of the abdominal cavity. As a result of research, the causative agents of aeromonosis and pseudo-monosis have not been isolated 
from artesian water. Virulent and highly virulent bacteria A. hydrophilaи P.capsulata were isolated from the contents of fertilized eggs, yolk sac of larvae and the abdominal cavity of juveniles of pink salmon, chum salmon and coho salmon. On average, fertilized eggs, larvae and juveniles were infected by more than $80.0 \%$. As a result of the research, infection of fertilized eggs with phycomycetes of the genus Saprolegnia was noted.

Whirling disease was observed in juveniles of salmon during their rearing in fish factories under aquaculture conditions. Juveniles up to the age of 6 months had this disease, bringing great economic losses to fish farming. From the cartilaginous tissue of the head of juvenile salmon, the pathogen Mixosoma cerebralis was identified at the plasmodial stage of development.

Dynamics of marine fish infection with pathogens

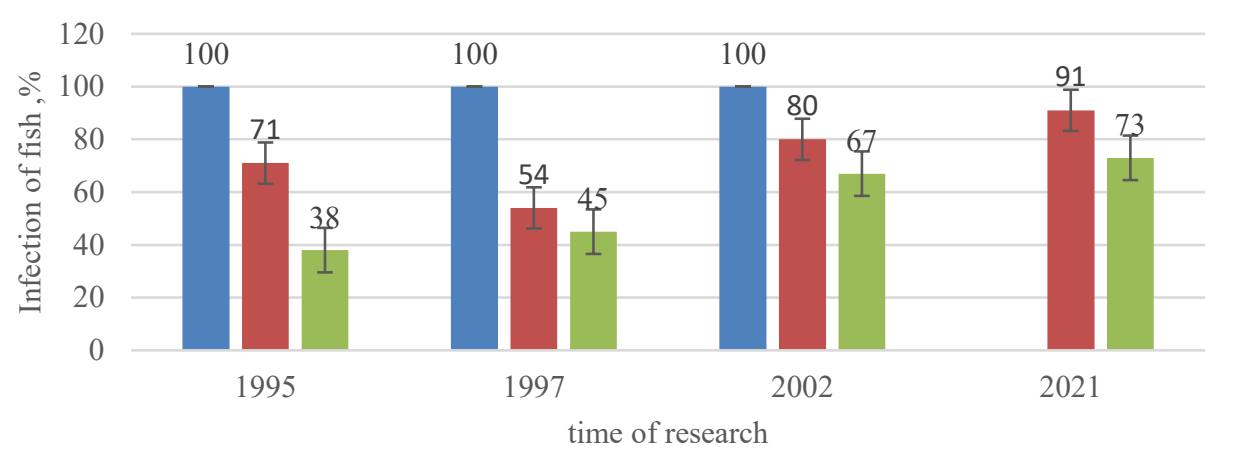

- Aeromonas - Anisakis Diphyllobothrium

Fig. 1. Dynamics of marine fish infection with pathogens.

Analysis of high rates $(100.0 \%)$ of retrospective data of ichthyopathological studies (Figure 1) shows that today there is an urgent need to study infectious diseases of fish of the North Sea of Okhotsk populations in a more detailed way. The average infection rate of fish with anisakid larvae in 2021 is higher $(91.0 \%)$ than in $2002(80.0 \%)$.

In commercial fish species: chum salmon (Oncorhynchus keta), pink salmon (Oncorhynchus gorbuscha), coho salmon (Oncorhynchus kisutch), herring (Clupea harengus pallasi), smelt (Hypomesus olidus), smelt (Osmerus eperlanus dentex), halibut (Hippoglossus hippoglossus stenolepis), halibut (Reinhardtius hippoglossoides matsuurae), flounder (Acanthopsetta nadeshnyi) saffron cod (Eleginus gracilis), pollock (Theragra chalcogramma) pathogens of zooanthroponous helminthiases have been registered. The most widespread are helminths of the Anisakidae and Diphyllobotriidae families (Table 1).

Fluctuations in the infection rates of fish are noted at the interspecific level. The infection of fish with anisakid larvae reaches high levels. The highest rates of invasion were observed in salmon species $(100.0 \%)$, and the lowest in flounder $(20.8 \%)$. The infestation of all fish species with diphyllobothriidae plerocercoids is much lower than that with anisakid larvae. Thus, the invasions of Diphyllobothrium luxi and Diphyllobothrium dendriticum in chum and pink salmon reach minimum values: from $2.8 \%$ to $20.0 \%$ and from $4.3 \%$ to $10.6 \%$, respectively, with an invasion intensity of 1.0 specimen. However, the infestation of smelt Diphyllobothrium sobolevi, pollock and saffron cod Pyramicocephalus phocarum significantly exceeds salmon species.

Smelt (Hypomesus olidus), smelt (Osmerus eperlanus dentex), halibut (Hippoglossus hippoglossus stenolepis), halibut (Reinhardtius hippoglossoides matsuurae), flounder (Acanthopsetta nadeshnyi), saffron cod (Eleginus gracilis) infested with Corynosoma 
strumosum. Although the indicators of invasions by this parasite reach high values $(98.9 \%$, with an invasion rate of -74.0), their epidemiological significance is low due to the localization of acanthellae only in the body cavity of the fish and on the internal organs.

Of the helminths that spoil the marketable appearance of fish, it is necessary to note the larvae of the cestodes Nybeliniasurminicola, which are located in the body cavity and in the muscles of fish.

\section{Conclusion}

The generalization of the results of long-term ichthyopathological research makes it possible to present the monitoring of fish diseases in the Magadan region. It has been revealed that in the Pacific anadromous salmon during the period of anadromous migration, aeromonosis, pseudomonosis, and saprolegniosis are manifested. The ways of transmission of infection to fish factories have been recorded. In aquaculture, during the reproduction of salmonids, problems arise with diseases of a bacterial and parasitic nature. All commercial fish species: chum salmon (Oncorhynchusketa), pink salmon (Oncorhynchusgorbuscha), coho salmon (Oncorhynchus kisutch), herring (Clupea harengus pallasi), smelt (Hypomesus olidus), smelt (Osmerus eperlanus dentex), halibut (Hippoglossus hippoglossus stenolepis), halibut (Reinhardtius hippoglossoides matsuurae), flounder (Acanthopsetta nadeshnyi) saffron cod (Eleginus gracilis), pollock (Theragra chalcogramma) are infested with pathogens of dangerous helminthic diseases of humans and animals. There are helminths that are not dangerous, but spoil the marketable appearance of fish products.

\section{References}

1. V.A. Musselius, V.F. Vanyatinskiy, A.A. Vikhman, Laboratory Workshop on Fish Diseases, 296 (Moscow.: Light and food industry, 1983)

2. https://economy.49gov.ru/activities/progress/results

3. A.S. Dovgalev, M.A. Valovaya, Yu.A. Piskunova, N.A. Romanenko, V.I. Khodakova, A.S. Artamoshin, Medical parasitology and parasitic diseases 6, 42-46 (1991)

4. A.M. Serdyukov, Diphyllobothriidae of Western Siberia, 120 (Novosibirsk: Science, 1979)

5. A.M. Serdyukov, Medical parasitology 2, 50-54 (1993)

6. G.P. Vyalova, Parasites of pink salmon and chum salmon of Sakhalin: Extended abstract of PhD dissertation, 22 (Yuzhno-Sakhalinsk, 1999)

7. E.A. Vitomskova, Helminths of commercial fish of northen Okhotsk region, dangerous for humans and animals, Extended abstract of PhD dissertation, 7-11 (Moscow, 2000)

8. E.A. Vitomskova, Helmintosthe Producer Co-operative Food-Fish Organization of the Nothern Part of Okhotsk Sea Basin, which are dangerous for the human beings and animals, 132 (Magadan: NEMARI RAAS, 2003)

9. A.M. Serdyukov, E.A. Vitomskova, E.A. Zaikova, G.R. Islamgaleeva, Epizootic state of diseases of salmonids of the genus Oncorhynchus in the northern part of the Sea of Okhotsk, Agriculture of the North at the turn of the millennium, 242-247 (Magadan, 2004)

10. Guidelines for determining the pathogenicity of aeromonads by the degree of DNA activity, Compliance with fish disease control instructions, 1, 150-151 (1998) 
11. Trust T.J., Sparrow R.A.H. The bacterial flora in the alimentary tract of freshwater salmonid fishes//Can. J. of microbiology. - 1974. - №20. -P. 1219-1228.

12. R.J. Roberts, Fish pathology, 289-389 (Bailliere Tindal, 1989) 